\title{
CONSERVING HABITAT THROUGH VOLUNTARY STEWARDSHIP: DOES IT WORK?
}

MARGARET A. SKEEL and ROBERT G. WARNOCK. Nature Saskatchewan, 2061860 Lorne Street, Regina, SK S4P 2L7. E-mail: <mskeel@naturesask.com>, <warnockr@accesscomm.ca>

\section{Introduction}

Conserving natural habitats is a priority for maintaining the biological diversity that sustains the natural processes upon which all living creatures depend. A number of strategies with varying levels of security and costs are being used to attain this goal, including voluntary habitat stewardship agreements, conservation easements, and land acquisition. Using Operation Burrowing Owl (OBO) as an example, we undertook a study to evaluate whether voluntary habitat stewardship agreements can be an effective strategy to conserve habitat.

What is voluntary habitat stewardship? It generally includes a "handshake" agreement-one that is not legally bindingbetween the landowner and a conservation organization to preserve or enhance natural habitat. It involves a personal commitment from the landowner, but no change in ownership of the land. In OBO, these are signed agreements and are indefinite in duration (they usually last until cancelled by the landowner). Although not legally binding, voluntary stewardship agreements do provide an opportunity for the conservation organization to strengthen the commitment of the landowner. This is accomplished by raising awareness of the elements of biologically diverse natural habitats and the value of biodiversity to ecosystem stability and the landowner's operation. In recognition of their participation, landowners may receive gate signs, certificates, educational materials, newsletters and extension services. In some cases, landowners also receive financial incentives for habitat enhancement; this usually involves an agreement to maintain the enhanced land for a designated period of time.

OBO was initiated in 1987 to address the rapid disappearance of grassland habitat and Burrowing Owls in Saskatchewan. Currently, only $20 \%$ of former grasslands remain as natural habitat, and in highly arable areas only $2 \%$ remain. ${ }^{3}$ Because most native prairie is privately owned, conservation initiatives largely depend on, or are driven by, landowners. Habitat loss and change, including fragmentation, and the associated low productivity and high mortality, have been identified as primary causes contributing to the Burrowing Owl's decline. ${ }^{1,10}$ In $\mathrm{OBO}$, landowners who have Burrowing Owls nesting on their land join the program, and continue to participate in OBO even if owls do not return to nest. The works of Hjertaas and Skeel et al. fully describe the OBO program..$^{4,8}$

Performance evaluation of conservation programs is needed to determine and improve their effectiveness. ${ }^{6}$ Until recently, voluntary stewardship programs have not been evaluated for their effectiveness in conserving habitat. In addition, direct 
evaluation of habitat conservation programs through comparison with historical data sets is rare, but increasingly important. Using a historical data set as a control sample, we examined whether the OBO program, one of the longest running voluntary habitat stewardship programs in Canada, has achieved conservation of grassland habitat. ${ }^{5}$ Our work is summarized here. The complete report has been published elsewhere. ${ }^{12}$

\section{Study area and methods}

Our study area was located in southern
Saskatchewan, represented by the Weyburn (62E) and Regina (72I) 1:250,000 map areas of the National Topographic Survey of Canada. This is the same area from which the control dataset was derived. ${ }^{5}$ We compared OBO parcels and randomlyselected parcels of land that were grassland in 1986 with land use in 1993 to determine if grassland retention was greater at $\mathrm{OBO}$ sites. Our sample was the 108 private grassland parcels enrolled in the OBO program in 1987-1988, and 98 of the 882 grassland parcels surveyed by Hjertaas and Lyon that

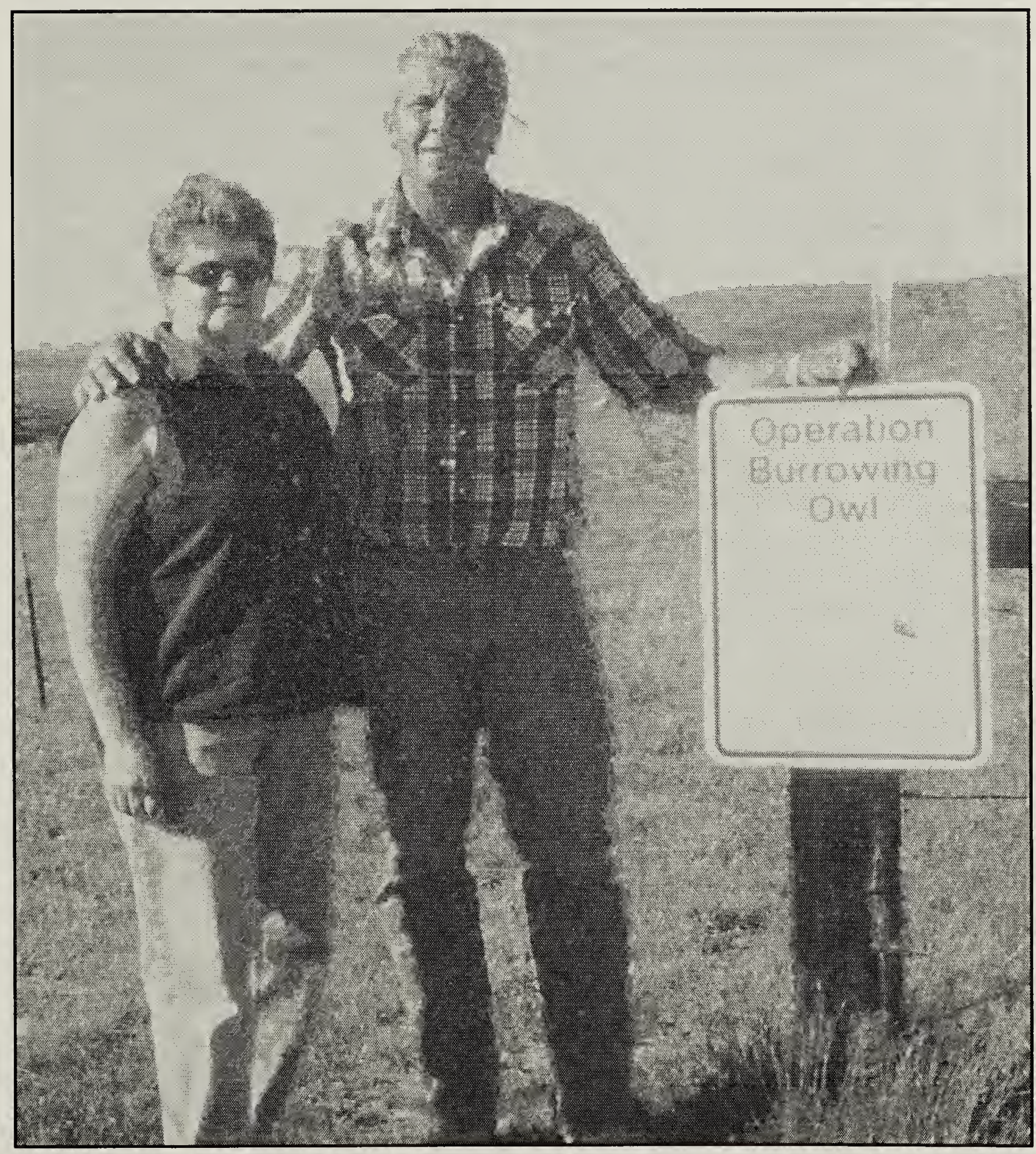

Figure 1. Voluntary Habitat Stewardship at work: Glenn and Josie Pettersen and their OBO sign Kim Dohms 
were systematically selected as random sites. These randomly-selected sites were all privately owned, were not known to support Burrowing Owls and had similar habitat and soil types as OBO sites.

All OBO and randomly-selected sites were assigned to one of three parcel size classes: less than 2 ha ( 5 acres), 2-12 ha (530 acres), and greater than 12 ha (30 acres), following Hjertaas and Lyon. ${ }^{5}$ Each site was also assigned to one of three agricultural soil suitability classes based on a combination of land system and soil type. ${ }^{2,7,9}$ Land use in 1993 at all sites was determined from satellite (LANDSAT) imagery using 1992 and 1993 Southern Saskatchewan Digital Land Cover Maps. Verification of a sample of $96 \mathrm{OBO}$ and randomly-selected sites suggested an accuracy of $78 \%$ even with the seven-year time lag, and it improved our estimated accuracy to $88 \%$. A correction factor for the apparent bias of the digital land cover data to underestimate the extent of grassland was used to adjust grassland retention for 21 sites.

\section{Results and discussion}

Grassland retention rates

Our study showed that grassland conservation was significantly higher at Operation Burrowing Owl sites than at the randomly-selected sites. At OBO sites $66 \%$ of the grassland area present in 1986 was still grassland in 1993. At randomly-selected sites, only $49 \%$ of the 1986 grassland was still present. These retention rates were for all parcel size and agricultural soil suitability classes combined.

When parcel size and agricultural soil suitability classes are looked at, it becomes apparent that OBO was important to grassland conservation at sites that were at greater risk from cultivation: i.e., at smaller grassland parcels ( 12 ha or less) and grassland parcels with excellent to average agricultural soils (Table 1). Grassland retention at these high-risk sites was significantly higher at OBO sites than at randomly-selected sites. Grassland retention did not differ between OBO and randomly-selected sites at the larger sites or sites with poor soils. At randomly-selected sites, smaller parcel sizes and better agricultural soils experienced higher loss to cultivation. ${ }^{12}$ At OBO sites, grassland retention was uniformly relatively high and parcel size or agricultural soil suitability was not a significant factor. ${ }^{12}$

Smaller parcels were at a greater risk, perhaps because they are logistically easier to cultivate or they may be considered to be of little economic value as grassland to the

Table 1: Grassland Retention at Operation Burrowing Owl and Randomly-Selected Sites from 1986 - 1993.

\begin{tabular}{|c|c|c|c|c|c|}
\hline & \multicolumn{2}{|c|}{ OBO Sites } & \multicolumn{2}{|c|}{ Randomly-Selected Sites } & \multirow[b]{2}{*}{$P$} \\
\hline & $\begin{array}{l}\text { Average } \\
\text { Retention }\end{array}$ & $\begin{array}{l}\text { Number of } \\
\text { Sites }\end{array}$ & $\begin{array}{l}\text { Average } \\
\text { Retention }\end{array}$ & $\begin{array}{l}\text { Number of } \\
\text { Sites }\end{array}$ & \\
\hline All Sites & $66 \%$ & 108 & $49 \%$ & 98 & 0.005 \\
\hline \multicolumn{6}{|c|}{ For Parcel Size Classes } \\
\hline$<2$ ha & $69 \%$ & 25 & $23 \%$ & 29 & $<0.001$ \\
\hline $2-12$ ha & $62 \%$ & 36 & $38 \%$ & 36 & 0.031 \\
\hline$>12$ ha & $68 \%$ & 47 & $82 \%$ & 33 & 0.113 \\
\hline \multicolumn{6}{|c|}{ For Agricultural Soil Suitability Classes } \\
\hline Excellent & $54 \%$ & 34 & $25 \%$ & 33 & 0.007 \\
\hline Average & $76 \%$ & 52 & $49 \%$ & 41 & 0.004 \\
\hline Poorest & $63 \%$ & 22 & $80 \%$ & 24 & 0.166 \\
\hline
\end{tabular}

\footnotetext{
${ }^{a}$ Bold indicates significantly different means.
} 
landowner. Better agricultural soils were also at greater risk of cultivation. Although larger grassland parcels (>12 ha) and grassland parcels with poor agricultural soils were at lower risk from cultivation, future changes in agricultural practices and climatic and economic conditions (government policies, crop prices) could contribute to changes in the risk from cultivation of these grassland sites.

\section{Conservation through voluntary stewardship}

Voluntary stewardship through the OBO program was successful in conserving grassland habitat, and in particular at the sites most at risk. The Burrowing Owl itself, both as a conservation focus and as a means to increase awareness by landowners, may have contributed to the success of the OBO program. A charismatic species such as the Burrowing Owl can serve as a conservation symbol to motivate conservation at many levels. ${ }^{13}$ Thus, conservation actions to maintain nesting owls (and other wildlife that might serve as conservation symbols) on the landscape may be important, as the presence of such wildlife encourages landowner commitment. Conservation actions to aid in the recovery of the endangered Burrowing Owl would include maintaining grassland habitat, focusing on vulnerable sites and sites that are most valuable to owls to attain highest productivity. Higher productivity may be encouraged through reducing fragmentation, as promoted through $\mathrm{OBO}$ habitat enhancement activities with landowners (seeding cultivated land that is adjacent to grassland back to perennial cover), and retaining wetlands (a source of prey species) nearby to nesting pairs. ${ }^{10,11}$

\section{Conclusions}

The Operation Burrowing Owl voluntary stewardship program had a significant impact on conservation (retention) of grassland habitat at enrolled sites, and even during an era of accelerated grassland loss in the area (the number of grassland parcels lost increased from $23 \%$ during $1979-1986$ to $42 \%$ during 1987-1993). Voluntary stewardship agreements are a low-cost conservation tool and, when warranted by risk assessment and cost, potentially can be scaled into a higher level of security such as a conservation easement. Does voluntary stewardship work? Can it achieve the desired conservation goals? Our study strongly suggests that it can.

\section{Acknowledgements}

Operation Burrowing Owl has been successful through the dedicated efforts of many individuals. We wish to thank participating OBO landowners, OBO volunteers, Nature Saskatchewan staff and summer students, and other conservation agencies including the Saskatchewan Watershed Authority and Saskatchewan Burrowing Owl Interpretive Centre. In addition, we thank again the people and organizations that assisted with the $\mathrm{OBO}$ effectiveness study." We are grateful for recent funding support from Canadian Council for Human Resources in the Environment Industry - Environmental Youth Program, Elsa Wild Animal Appeal of Canada, Environment Canada - EcoAction, Government of Canada Habitat Stewardship Program for Species at Risk, Human Resources Development Canada - Summer Career Placement Programs, Nature Saskatchewan member donations, SaskEnergy - TransGas, Saskatchewan Environment - Fish and Wildlife Development Fund, and World Wildlife Fund \& Environment Canada - Endangered Species Recovery Fund. Nature Saskatchewan receives funding from Saskatchewan Lotteries.

1. CLAYTON, K.M. AND J.K. SCHMUTZ. 1999. Is the decline of Burrowing Owls Speotyto cunicularia in prairie Canada linked to changes in Great Plains ecosystems? Bird Conservation Intemational 9: 163185.

2. FLORY, P.M. 1980. Terrestrial wildlife habitat inventory of the Regina (72 I) map area. Saskatchewan Tourism and Renewable Resources, Wildlife Technical Report 80-1, Regina, Saskatchewan.

3. HAMMERMEISTER, A.M., D. GAUTHIER and K. MCGOVERN. 2001. Saskatchewan's Native Prairie: 
Taking Stock of a Vanishing Ecosystem and Dwindling Resource. Native Plant Society of Saskatchewan Inc., Saskatoon, Saskatchewan.

4. HJERTAAS, D.G. 1997. Operation Burrowing Ow1 in Saskatchewan. Pages 112-116 in J.L. Lincer and K. Steenhof, editors. The Burrowing Owl, its biology and management: including the proceedings of the first international symposium. Raptor Research Report No. 9.

5. HJERTAAS, D.G. and W. LYON. 1987. A Stratified Random Survey for Burrowing Owls on the Weyburn (62E) and Regina (72I). Map Areas. Saskatchewan Parks, Recreation and Culture, Wildlife Technical Report 87-2, Regina, Saskatchewan.

6. KLEIMAN, D.G., R.P. READING, B.J. MLLLER, T.W. CLARK, J.M. SCOTT, J. ROBINSON, R.L. WALLACE, R.J. CABIN and F. FELLEMAN. 2000. Improving the evaluation of conservation programs. Conservation Biology 14:356-365.

7. MITCHELL, J., H.C. MOSS and J.S. CLAYTON. 1944. Soil Survey of Southern Saskatchewan Townships 1 to 48 Inclusive. University of Saskatchewan, Soil Survey Report No.12, Saskatoon, Saskatchewan.
8. SKEEL, M.A., J. KEITH and C.S. PALASCHUK. 2001. A population decline of Burrowing Owls in Saskatchewan documented by Operation Burrowing Owl. Journal of Raptor Research 35: 371-377.

9. STELFOX, H.A. 1979. Terrestrial Wildlife Habitat Inventory of the Weyburn (62E) - Virden (62F) Map Area. Saskatchewan Tourism and Renewable Resources, Wildlife Technical Report 79-6, Regina, Saskatchewan.

10. WARNOCK, R. 1997. Is habitat fragmentation a factor in the decline of the Burrowing Owl in Saskatchewan? Blue Jay: 222-228.

11. WARNOCK, R.G. and M.A. SKEEL. 2002. Habitat features important to Burrowing Owl breeding success in Saskatchewan. Blue Jay: 135-145.

12. WARNOCK, R.G. and M.A. SKEEL. 2004. The effectiveness of voluntary habitat stewardship in conserving grassland: Case of Operation Burrowing Owl in Saskatchewan. Environmental Management 33: 306-317.

13. WILSON, E. O. 1992. Biodiversity of Life. W.W. Norton, New York, NY, USA.

\section{NORTHERN FLICKER}

\author{
Yellow-hammer foraging \\ drums the earth for ants \\ scarlet crescent on his nape \\ top of head a gray \\ side of head vinaceous tan \\ and moustache of black
}

spotted breast a salmon-buff

with a dark cravat

back and coverts olive-brown

barred with dusky jet

rump a bar of showy white

underbody beige

under side of wings and tail

golden gilt or yellow

what a smart le pic doré

what a handsome fellow 